\title{
Effects of Thermal Treatment, Ultrasonication, and Sunlight Exposure on Antioxidant Properties of Honey
}

\author{
Isıl İşlem, Ultrasonikasyon ve Güneş Işığına Maruz Kalmanın Balın \\ Antioksidan Özelliklerine Etkileri
}

\author{
(D) Görkem YALÇIN* \\ Isparta University of Applied Sciences, Gelendost Vocational School, Department of Pharmacy Services, Isparta, Turkey
}

\begin{abstract}
Objectives: This study aimed to determine effects of controlled heating, ultrasonication, and sunlight on antioxidant capacity, total phenolic content (TPC), and total flavonoid content (TFC) of honey.

Materials and Methods: Honey was subjected to thermal treatment (for $5-20$ min at $30-80^{\circ} \mathrm{C}$ ), ultrasonication (for $5-20 \mathrm{~min}$ at $37 \mathrm{kHz}$ frequency), and sunlight (for 1-10 days), and the impact of these treatments on antioxidant capacity, TPC, and flavonoid contents was evaluated. One-Way ANOVA, followed by Tukey's post-hoc test, was performed to compare the differences between experimental results.

Results: Antioxidant quality of samples heated at $60^{\circ} \mathrm{C}$ and $80^{\circ} \mathrm{C}$ were negatively affected when compared to untreated samples ( $p<0.05$ ); however, there were no statistically significant differences between untreated samples and samples heated at $30^{\circ} \mathrm{C}$ and $45^{\circ} \mathrm{C}$. On the other hand, ultrasonication of honey samples for 60 min enhanced the antioxidant properties when compared to untreated samples ( $p<0.05$ ). In addition, while exposure to sunlight for 10 days decreased the TPC, the TFC and antioxidant capacity began to decrease after 6 days $(p<0.05)$.

Conclusion: The results suggest that producers and consumers should consider the adverse effects of sunlight and temperature on antioxidative quality of honey. Additionally, ultrasonication technique has the advantage of preserving the antioxidant properties of honey.
\end{abstract}

Key words: Honey, temperature, ultrasonication, sunlight, antioxidative quality

Öz

Amaç: Bu çalışma, kontrollü ısıtma, ultrasonikasyon ve güneș ışığının balın antioksidan kapasitesi, toplam fenolik içeriği (TPC) ve toplam flavonoid içeriği (TFC) üzerindeki etkilerini belirlemeyi amaçlamıştır.

Gereç ve Yöntemler: Bal, ısıl işleme (30-80 C'de 5-20 dakika), ultrasonikasyona (37 kHz frekansında 5-20 dakika) ve güneş ışığına (1-10 gün) tabi tutulmuş ve bu uygulamaların antioksidan kapasite, TPC ve flavonoid içerikleri değerlendirilmiştir. Deneysel sonuçlar arasındaki farkları karşılaştırmak için tek yönlü ANOVA ve ardından Tukey'nin post-hoc testi yapılmıştır.

Bulgular: $60^{\circ} \mathrm{C}$ ve $80^{\circ} \mathrm{C}$ 'de Isıtılan numunelerin antioksidan kalitesi, işlem görmemiş numunelere göre olumsuz etkilenmiștir ( $p<0,05$ ); bununla birlikte, işlenmemiş numuneler ile $30^{\circ} \mathrm{C}$ ve $45^{\circ} \mathrm{C}$ ' de ısıtılan numuneler arasında istatistiksel olarak anlamlı bir fark belirlenmemiştir. Diğer taraftan, bal örneklerinin 60 dakika ultrasonikasyonu, işlem görmemiş örneklere kıyasla antioksidan özelliklerini arttırmıştır ( $p<0,05)$. Ayrıca 10 gün güneș ışığına maruz kalma TPC'yi azaltırken, 6 gün sonra TFC ve antioksidan kapasite azalmaya başlamıştır $(p<0,05)$.

Sonuç: Sonuçlar, üreticilerin ve tüketicilerin, güneşışığının ve sıcaklığın balın antioksidan kalitesi üzerindeki olumsuz etkilerini göz önünde bulundurmaları gerektiğini göstermektedir. Ek olarak, ultrasonikasyon tekniği balın antioksidan özelliklerini koruma avantajına sahiptir.

Anahtar kelimeler: Bal, sıcaklık, ultrasonikasyon, güneș ışı̆̆ı, antioksidan kalite

The Abstract was presented in the 8. Black Sea Basin Conference on Analytical Chemistry, 9-11 May 2018, İstanbul-Şile/Turkey

*Correspondence: gorkemy1@gmail.com, Phone: +90 2463814280 , ORCID-ID: orcid.org/0000-0002-8705-0320

Received: 17.01.2021, Accepted: 22.03.2021

๑Turk J Pharm Sci, Published by Galenos Publishing House. 


\section{INTRODUCTION}

Honey is a natural product generated by honeybees; it has great market potential due to its health benefits in humans. Honey is a well-known source of enzymatic and non-enzymatic antioxidants, such as glucose oxidase, catalase, phenolics, flavonoids, vitamins, proteins, and Maillard reaction products. Phenolics are the main compounds in honey, which contribute significantly to the antioxidant properties of honey. ${ }^{2}$ However, the antioxidant activity varies, depending on the floral source, season, and environmental factors. ${ }^{3}$

Honey has a unique combination of components, a characteristic that makes it a valuable diet for consumers. However, raw honey is not normally commercialized, as further treatment is needed for large scale marketing. ${ }^{4,5}$ Controlled heating is one of the important steps in processing honey. It can demolish the bacteria yeast that cause undesirable fermentation during storage of the product; it also facilitates liquefaction, so as to obtain a fluidy and non-crystallized product. ${ }^{4-6}$ Besides thermal treatments, ultrasonication has been also used as an alternative to promote the marketability of honey. ${ }^{7}$

Honey is inevitably exposed to sunlight from the period of production to consumption. Sunlight exposure increases ultraviolet (UV) radiation. It is well-known that UV radiation adversely affects the quality of foods, ${ }^{8}$ but there is no information on the effects of natural UV radiation on the antioxidant properties of honey.

Given the health benefits and demand for high quality honey, the preservation and enhancement its antioxidant properties during processing and storage are considerably important. Therefore, this study aimed to determine the antioxidant capacity, total phenolic content (TPC), and total flavonoid content (TFC) of honey, following its exposure to controlled heating, ultrasonication, and sunlight.

\section{MATERIALS AND METHODS}

\section{Materials}

Three bottles of same brands of honey were purchased from a common chain market in Turkey. The honey brand chosen for this study is well-known in Turkey. The brand officially declared that they own British Retail Consortium certificate and that all chemical and physical analysis were performed to assure the authenticity of the honey.

\section{Methods}

\section{Thermal treatment}

Samples were separately subjected to thermal processing in a water bath for $5,10,15$, and $20 \mathrm{~min}$ at $30^{\circ} \mathrm{C}, 45^{\circ} \mathrm{C}, 60^{\circ} \mathrm{C}$, and $80^{\circ} \mathrm{C}$. Afterward, antioxidant capacity, TPC, and TFC of the samples were determined at room temperature.

\section{Ultrasonication}

Sonication of the samples was performed at $37 \mathrm{kHz}$ frequency for $5,15,30$, and 60 min using an ultrasonic cleaning bath.

\section{Exposure to sunlight}

Samples were placed outdoor during daytime (average maximum temperature: $26.0^{\circ} \mathrm{C}$ ) and night time (average minimum temperature: $15.5^{\circ} \mathrm{C}$ ) in May for $1,3,6$, and 10 days.

\section{Analysis of antioxidant capacity}

\section{Cupric reducing antioxidant capacity (CUPRAC)}

CUPRAC was determined according to the method described by Apak et al. ${ }^{9}$ In brief, $1 \mathrm{~g}$ of processed honey sample was dissolved in $2.5 \mathrm{~mL}$ of distilled water. Then, $0.1 \mathrm{~mL}$ of the solution was mixed with $0.75 \mathrm{~mL}$ of $\mathrm{CuCl}_{2}(10 \mathrm{mM}), 0.75 \mathrm{~mL}$ of neocuproine (7.5 mM), $0.75 \mathrm{~mL}$ of $\mathrm{CH}_{3} \mathrm{COONH}_{4}$ buffer (1M, pH: 7.0 ), and 0.75 $\mathrm{mL}$ of distilled water. Absorbance was measured at $450 \mathrm{~nm}$ after $30 \mathrm{~min}$. Trolox was used as a reference standard. Results were expressed as $\mu \mathrm{mol}$ Trolox equivalent (TE) per one gram ( $\mu \mathrm{mol} \mathrm{TE} / \mathrm{g}$ ).

\section{Trolox equivalent antioxidant capacity (TEAC)}

TEAC was determined according to the method described by on Re et al. ${ }^{10}$ In brief, $0.1 \mathrm{~mL}$ of honey solution $(1 \mathrm{~g} / 2.5 \mathrm{~mL})$ was mixed with $2 \mathrm{~mL}$ of ABTS.+ solution. After $15 \mathrm{~min}$, absorbance was measured at $734 \mathrm{~nm}$. A standard curve was constructed using Trolox and the results were expressed as $\mu \mathrm{mol} \mathrm{TE} / \mathrm{g}$.

\section{TPC and TFC}

TPC was determined according to the method described by Fu et al. ${ }^{11}$ In brief, $0.1 \mathrm{~mL}$ of honey solution $(1 \mathrm{~g} / 2.5 \mathrm{~mL}$ ) was mixed with $1.0 \mathrm{~mL}$ of $1: 10$ diluted Folin-Ciocalteu reagent. 1.0 $\mathrm{mL}$ of saturated sodium carbonate solution was added after 4 min. This mixture was incubated for $2 \mathrm{~h}$ at room temperature. The absorbance of mixture was measured at $760 \mathrm{~nm}$ after incubation. Gallic acid (GA) was used as standard to produce the calibration curve. The results were expressed as $\mathrm{mg}$ of gallic acid equivalent (GAE) per $100 \mathrm{~g}$.

TFC was determined according to the method described by Meda et al..$^{12}$ In brief, $1.5 \mathrm{~mL}$ of $2 \%$ aluminum trichloride in methanol was mixed with the same volume of honey solution (1 g/2.5 mL). After $10 \mathrm{~min}$, absorbance was measured at 415 $\mathrm{nm}$. A standard curve was constructed using quercetin and the results were expressed as $\mathrm{mg}$ of quercetin equivalent (QE) per $100 \mathrm{~g}$ (mg QE/100g).

\section{Statistical analysis}

Statistical analysis was done using GraphPad Prism 5 (Prism 5 for Windows Version 5.03, GraphPad Software, Inc) and Microsoft Excel. All experiments were conducted in triplicate. One-Way ANOVA was performed and significant differences between means were determined by Tukey's post-hoc test at a significance level of $p<0.05$.

\section{RESULTS AND DISCUSSION}

\section{Effect of thermal treatment}

Table 1 shows the antioxidant capacity, TPC, and TFC of honey before and after heat treatment. For untreated samples, CUPRAC, TEAC, TPC, and TFC were found to be 2.75, 1.14 ( $\mu \mathrm{mol} \mathrm{TE} / \mathrm{g}$ ), 
27.75 (mg GAE/100g), and 6.76 (mg QE/100g), respectively. For samples heated at $30^{\circ} \mathrm{C}$ and $45^{\circ} \mathrm{C}$ for $5 \mathrm{~min}$, the highest TPC and TFC values, respectively, as compared to the rest, were obtained. In the cases of CUPRAC and TEAC, the highest results were obtained for untreated samples. On the contrary, antioxidant capacity, TPC, and TFC of samples decreased with the increase of treatment temperature. To ascertain whether these differences are statistically significant, One-Way ANOVA, followed by Tukey's post-hoc test, was applied to the data. As seen in Table 1, statistical differences between the untreated samples and samples subjected to $60^{\circ} \mathrm{C}$ (in CUPRAC and TFC assays) and $80^{\circ} \mathrm{C}$ heating (in all assays) were significant. Also, findings revealed that the process time and the treatment temperature affected the antioxidant capacity, TPC, and TFC of the samples.

Honey is rich in natural antioxidants, such as enzymes, vitamins, phenolic acids, and flavonoids. ${ }^{13}$ However, these compounds may undergo several irreversible changes during thermal treatments. ${ }^{1}$ Escriche et al. ${ }^{4}$ evaluated the effect of industrial heat treatment on the phenolic compounds of Spanish honeys. According to their results, a significant decrease in the concentration of some phenolic compounds in these honeys was observed after the thermal treatment. Kowalski ${ }^{14}$ investigated the impact of heating at $90^{\circ} \mathrm{C}$ for 60 min on antioxidant properties of honey through TPC and ABTS.+ assays. It was observed that there was a significant decrease in the antioxidant properties of honeydew honey after processing. Chaikham and Prangthip ${ }^{15}$ reported that TPC, TFC, and antioxidant capacity (measured by FRAP and DPPH assays) of longan-flower honey diminished after heating at $100^{\circ} \mathrm{C}$ for $5 \mathrm{~min}$.

Finally, heating honey at high temperatures could degrade their antioxidant compounds content, ${ }^{16}$ and this could explain why the antioxidant capacity, TPC, and TFC of the treated honey samples decreased when compared to those of the untreated samples.

\section{Effect of ultrasonication}

Results of the impact of ultrasonication on antioxidant properties of honey are shown in Table 2. The values of treated samples increased with increase of the treatment time as compared to the values of the untreated samples. However, statistical

Table 1. Effects of thermal treatment on antioxidant capacity, TPC, and TFC of honey

\begin{tabular}{|c|c|c|c|c|}
\hline & Method & & & \\
\hline & CUPRAC* & TEAC* & TPC** & $\mathrm{TFC}^{\star * *}$ \\
\hline Untreated sample & $2.75 \pm 0.10$ & $1.14 \pm 0.02$ & $27.75 \pm 0.57$ & $6.76 \pm 0.06$ \\
\hline \multicolumn{5}{|l|}{$30^{\circ} \mathrm{C}$ temperature } \\
\hline $5 \mathrm{~min}$ & $2.66 \pm 0.05$ & $1.04 \pm 0.03$ & $28.21 \pm 0.07$ & $6.70 \pm 0.07$ \\
\hline $10 \mathrm{~min}$ & $2.62 \pm 0.08$ & $1.04 \pm 0.02$ & $27.77 \pm 1.25$ & $6.78 \pm 0.14$ \\
\hline $15 \mathrm{~min}$ & $2.67 \pm 0.15$ & $1.07 \pm 0.07$ & $27.98 \pm 0.69$ & $6.75 \pm 0.08$ \\
\hline $20 \mathrm{~min}$ & $2.69 \pm 0.11$ & $1.08 \pm 0.02$ & $26.59 \pm 0.79$ & $6.72 \pm 0.14$ \\
\hline \multicolumn{5}{|l|}{$45^{\circ} \mathrm{C}$ temperature } \\
\hline $5 \min$ & $2.71 \pm 0.07$ & $1.10 \pm 0.02$ & $27.73 \pm 0.38$ & $6.79 \pm 0.24$ \\
\hline $10 \mathrm{~min}$ & $2.68 \pm 0.10$ & $1.08 \pm 0.01$ & $27.94 \pm 0.85$ & $6.69 \pm 0.18$ \\
\hline $15 \mathrm{~min}$ & $2.69 \pm 0.12$ & $1.07 \pm 0.06$ & $27.59 \pm 1.08$ & $6.57 \pm 0.11$ \\
\hline $20 \mathrm{~min}$ & $2.73 \pm 0.13$ & $1.08 \pm 0.03$ & $27.82 \pm 0.78$ & $6.50 \pm 0.05$ \\
\hline \multicolumn{5}{|l|}{$60^{\circ} \mathrm{C}$ temperature } \\
\hline $5 \mathrm{~min}$ & $2.47 \pm 0.07$ & $1.06 \pm 0.01$ & $27.60 \pm 0.45$ & $6.50 \pm 0.04$ \\
\hline $10 \mathrm{~min}$ & $2.41 \pm 0.11^{a}$ & $1.03 \pm 0.02$ & $27.12 \pm 0.31$ & $6.17 \pm 0.12^{d}$ \\
\hline $15 \mathrm{~min}$ & $2.38 \pm 0.15^{\mathrm{a}}$ & $1.02 \pm 0.04$ & $26.86 \pm 0.28$ & $5.79 \pm 0.15^{d}$ \\
\hline $20 \mathrm{~min}$ & $2.30 \pm 0.01^{\mathrm{a}}$ & $1.03 \pm 0.06$ & $26.23 \pm 0.66$ & $5.62 \pm 0.11^{d}$ \\
\hline \multicolumn{5}{|l|}{$80^{\circ} \mathrm{C}$ temperature } \\
\hline $5 \mathrm{~min}$ & $2.32 \pm 0.10^{\mathrm{a}}$ & $1.02 \pm 0.01$ & $27.12 \pm 0.18$ & $6.30 \pm 0.14^{d}$ \\
\hline $10 \mathrm{~min}$ & $2.32 \pm 0.12^{\mathrm{a}}$ & $0.96 \pm 0.01^{\mathrm{b}}$ & $27.05 \pm 0.74$ & $6.01 \pm 0.16^{d}$ \\
\hline $15 \mathrm{~min}$ & $2.22 \pm 0.07^{\mathrm{a}}$ & $0.96 \pm 0.01^{\mathrm{b}}$ & $24.90 \pm 1.03^{c}$ & $5.69 \pm 0.18^{d}$ \\
\hline $20 \mathrm{~min}$ & $2.19 \pm 0.02^{\mathrm{a}}$ & $0.96 \pm 0.04^{b}$ & $24.45 \pm 0.70^{c}$ & $5.74 \pm 0.12^{d}$ \\
\hline
\end{tabular}

a, b, c, dThe rows that do not share the same superscripts are significantly different from each other in Tukey's post-hoc test $(p<0.05)$. ${ }^{*} \mu m o l$ TE/g, ${ }^{* *} \mathrm{mg} G A E / 100 \mathrm{~g}$, ***mg QE/100g, CUPRAC: Cupric reducing antioxidant capacity, TEAC: Trolox equivalent antioxidant capacity, TPC: Total phenolic content, TFC: Total flavonoid content, GAE: Gallic acid equivalent, QE: Quercetin equivalent 
differences between the samples subjected to ultrasonication for $60 \mathrm{~min}$, and the untreated samples in terms of TPC, TFC, and CUPRAC were observed. In the case of TEAC assay, there were no significant differences between the treated and untreated samples. The differences between the antioxidant capacity assays CUPRAC and TEAC were due to the difference in the two assays. ${ }^{17,18}$

Ultrasonication is an alternative and innovative technology to obtain fluidy and non-crystallized products. It is more effective to preserve the nutritional I values of honey by this method rather than thermal treatments. ${ }^{7,15}$ However, there are limited data on the impact of ultrasonication on antioxidant properties of honey. Similar to the current assay, Chaikham and Prangthip ${ }^{15}$ reported that the TPC, TFC, and antioxidant capacity of honey increased after processing for $20 \mathrm{~min}$. Pollen is one of the important contents of honey; ${ }^{13}$ it has multiple essential components, such as proteins, vitamins, and phenolic compounds. ${ }^{19}$ Ultrasonication has the capability to increase the permeability of plant tissues caused by cell disruption, thereby resulting in the liberation of all the compounds present in the cell. ${ }^{20}$ In view of the fact that a pollen is produced by plants as a male cell, existing antioxidant compounds in pollens could be released after ultrasonication, thereby causing an increase in the TPC, TFC, and antioxidant capacity of honey.

Apart from the limited studies relevant to the impact of ultrasonication on antioxidant properties of honey, many studies have been conducted to examine the influence of ultrasonication in preserving the nutrional qualities of fruit juices, although its positive effect in terms of antioxidant properties have been demonstrated. $21-23$

\section{Effect of sunlight exposure}

Table 3 shows the effects of sunlight exposure on the TPC, TFC, and antioxidant capacity of honey. TPC of the samples exposed to sunlight began to change after 10 days, whereas exposure to sunlight caused changes in the TFC and TEAC of the samples after 6 days ( $p<0.05$ ). However, CUPRAC did not change significantly in any of the samples when compared with the untreated sample. Direct sunlight exposure initiates the generation of free radicals that accelerate the degradation reactions that adversely affect the quality of foods and beverages. ${ }^{8}$ This could explain the decrease of TPC, TFC, and antioxidant capacity of the honey. Until now, there is no study examining the influence of direct sunlight exposure on the antioxidant capacity, TPC, and TFC of honey. However, several authors report that sunlight induced quality loss of fruit products, such as pummelo (Citrus maxima) essential oil24 and strawberry juice. ${ }^{25}$

\section{CONCLUSION}

The treatments significantly affected the antioxidant properties of honey, depending on the processing time. Thermal treatment and sunlight exposure had a negative influence on the antioxidant quality of honey. However, ultrasonication significantly increased the values of these parameters in all assays, except TEAC assay, in which the increment was statistically significant. Therefore,

Table 2. Effects of ultrasonication on antioxidant capacity, TPC, and TFC of honey

\begin{tabular}{|c|c|c|c|c|c|}
\hline \multirow{3}{*}{ Method } & \multirow{3}{*}{ Untreated sample } & \multicolumn{4}{|c|}{ Ultrasonication } \\
\hline & & \multicolumn{4}{|c|}{ Process time (min) } \\
\hline & & 5 & 15 & 30 & 60 \\
\hline TEAC* & $1.14 \pm 0.02$ & $1.19 \pm 0.03$ & $1.19 \pm 0.02$ & $1.22 \pm 0.06$ & $1.24 \pm 0.08$ \\
\hline TPC** & $27.75 \pm 0.57$ & $28.16 \pm 0.41$ & $29.13 \pm 0.80$ & $29.18 \pm 1.22$ & $30.85 \pm 0.56^{c}$ \\
\hline
\end{tabular}

a, c, dShows significant differences between the treated and untreated samples according to Tukey's post-hoc test ( $p<0.05$ ). ${ }^{*} \mu \mathrm{mol}$ TE/g, ${ }^{* *} \mathrm{mg}$ GAE/100g, ${ }^{* *} \mathrm{mg}$ QE/100g, TPC: Total phenolic content, TFC: Total flavonoid content, CUPRAC: Cupric reducing antioxidant capacity, TEAC: Trolox equivalent antioxidant capacity, GAE: Gallic acid equivalent, QE: Quercetin equivalent

Table 3. Effects of sunlight exposure on antioxidant capacity, TPC, and TFC of honey

\begin{tabular}{|c|c|c|c|c|c|}
\hline \multirow{3}{*}{ Method } & \multirow{3}{*}{ Untreated sample } & \multicolumn{4}{|c|}{ Sunlight exposure } \\
\hline & & \multicolumn{4}{|c|}{ Process time (day) } \\
\hline & & 1 & 3 & 6 & 10 \\
\hline CUPRAC* & $2.75 \pm 0.10$ & $2.72 \pm 0.04$ & $2.58 \pm 0.04$ & $2.55 \pm 0.09$ & $2.50 \pm 0.11$ \\
\hline TEAC* & $1.14 \pm 0.02$ & $1.11 \pm 0.04$ & $1.11 \pm 0.05$ & $1.01 \pm 0.02^{b}$ & $1.01 \pm 0.06^{b}$ \\
\hline TPC** & $27.75 \pm 0.57$ & $27.88 \pm 0.42$ & $26.98 \pm 1.66$ & $25.83 \pm 1.15$ & $24.49 \pm 0.96^{c}$ \\
\hline $\mathrm{TFC}^{\star \star *}$ & $6.76 \pm 0.06$ & $6.63 \pm 0.12$ & $6.53 \pm 0.10$ & $6.27 \pm 0.08^{d}$ & $6.26 \pm 0.18^{d}$ \\
\hline
\end{tabular}

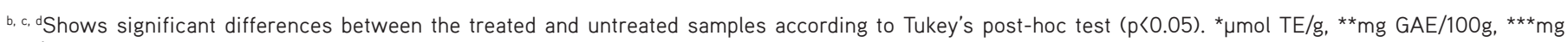

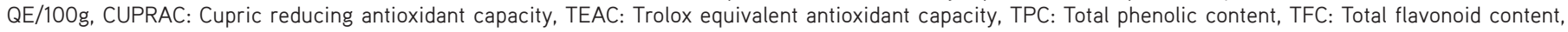
GAE: Gallic acid equivalent, QE: Quercetin equivalent 
ultrasonication could be an alternative technique for preserving the antioxidant properties of honey instead of industrial thermal treatment. On the other hand, it is suggested that producers and consumers should consider the negative effects of sunlight on the antioxidants properties of honey during storage, since exposure of the honey samples to sunlight resulted in a decrease in the antioxidant capacity, TPC, and TFC.

\section{ACKNOWLEDGMENTS}

The author wish to thank Ege of the University Faculty of Pharmacy Pharmaceutical Sciences Research Centre (FABAL).

Conflict of interest: No conflict of interest was declared by the author. The author is solely responsible for the content and writing of this paper.

\section{REFERENCES}

1. Wilczynska A. Effect of filtration on colour, antioxidant activity and total phenolics of honey. LWT-Food Sci Technol. 2014;57:767-774.

2. Akhmazillah MFN, Farid MM, Silva FVM. High pressure processing (HPP) of honey for the improvement of nutritional value. Innov. Food Sci Emerg Technol. 2013;20:59-63.

3. Gheldof N, Wang $X H$, Engeseth NJ. Identification and quantification of antioxidant components of honeys from various floral sources. J Agric Food Chem. 2002;50:5870-5877.

4. Escriche I, Kadar M, Juan-Borras M, Domenech E. Suitability of antioxidant capacity, flavonoids and phenolic acids for floral authentication of honey. Impact of industrial thermal treatment. Food Chem. 2014;142:135-143.

5. Wang X, Gheldof HN, Engeseth NJ. Effect of processing and storage on antioxidant capacity of honey. J Food Sci. 2004;69:96-101.

6. Escriche I, Visquert M, Carot JM, Domenech E, Fito P. Effect of honey thermal conditions on hydroxymethylfurfural content prior to pasteurization. Food Sci Technol Int. 2008;14:29-35.

7. Subramanian R, Hebbar HU, Rastogi. NK. Processing of honey: A Review. Int J Food Prop. 2007;10:127-143.

8. Huvaere K, Skibsted LH. Flavonoids protecting food and beverages against light. J Sci Food Agric. 2014;95:20-35.

9. Apak R, Güçlü K, Özyürek M, Çelik SE. Mechanism of antioxidant capacity assays and the CUPRAC (cupric ion reducing antioxidant capacity) assay. Microchim Acta. 2008;160:413-419.

10. Re R, Pellegrini N, Proteggente A, Pannala A, Yang M, Rice-Evans C. Antioxidant activity applying an improved ABTS radical cation decolourisation assay. Free Radic Biol Med. 1999;26:1231-1237.

11. Fu L, Xu BT, Xu XR, Gan RY, Zhang Y, Xia EQ Li HB. Antioxidant capacities and total phenolic contents of 62 fruits. Food Chem. 2011;129:345-350.
12. Meda A, Lamien CE, Romito M, Jeanne Millogo J, Nacoulma OG. Determination of the total phenolic, flavonoid and proline contents in Burkina Fasan honey, as well as their radical scavenging activity. Food Chem. 2005;91:571-577.

13. Da Silva PM, Gauche C, Gonzaga LV, Costa ACO, Fett R. Honey: Chemical composition, stability and authenticity. Food Chem. 2016;196:309-323.

14. Kowalski S. Changes of antioxidant activity and formation of 5-hydroxymethylfurfural in honey during thermal and microwave processing. Food Chem. 2013;141:1378-1382.

15. Chaikham P, Prangthip P. Alteration of antioxidative properties of longan flower- honey after high pressure, ultra-sonic and thermal processing. Food Biosci. 2015;10:1-7.

16. Fauzi NA, Farid MM. High-pressure processing of Manuka honey: brown pigment formation, improvement of antibacterial activity and hydroxymethylfurfural content. Int J Food Sci Technol. 2015;50:178-185.

17. Apak R, Güçlü K, Demirata B, Özyürek M, Çelik SA, Bektaşoğlu B, Berker $\mathrm{KI}$. Comparative evaluation of various total antioxidant capacity assays applied to phenolic compounds with the CUPRAC assay. Molecules. 2007;12:1496-1547.

18. Tafulo PAR, Queiros RB, Delerue-Matos CM, Sales MGF. Control and comparison of the antioxidant capacity of beers. Food Res Int. 2010;43:1702-1709.

19. Krystyjan M, Gumul D, Ziobro R, Korus A. The fortification of biscuits with bee pollen and its effect on physicochemical and antioxidant properties in biscuits. LWT-Food Sci Technol. 2015;63:640-646.

20. Altemimi A, Choudhary R, Watson DG, Lightfoot DA. Effects of ultrasonic treatments on the polyphenol and antioxidant content of spinach extracts. Ultrason. Sonochem. 2015;24:247-255.

21. Aadil RM, Zenga XA, Han Z, Sun DW. Effects of ultrasound treatments on quality of grapefruit juice. Food Chem. 2013;141:3201-3206.

22. Bhat R, Kamaruddin NSBC, Min-Tze L, Karim AA. Sonication improves kasturi lime (Citrus microcarpa) juice quality. Ultrason Sonochem. 2011;18:1295-1300.

23. Zafra-Rojas QY, Cruz-Cansino N, Ramirez-Moreno E, Delgado-Olivares L, Villanueva-Sanchez J, Alanis-Garcia E. Effects of ultrasound treatment in purple cactus pear (Opuntia ficus-indica) juice. Ultrason Sonochem. 2013;20:1283-1288.

24. Sun $H, N i H$, Yang $Y$, Wu L, Cai $H$, Xiao A, Chen F. Investigation of sunlight-induced deterioration of aroma of pummelo (Citrus maxima) essential oil. J Agric Food Chem. 2014;62:11818-11830.

25. Wang Z, Zhang $\mathrm{M}, \mathrm{Wu}$ Q. Effects of temperature, $\mathrm{pH}$, and sunlight exposure on the color stability of strawberry juice during processing and storage. LWT-Food Sci. Technol. 2015;60:1174-1178. 